\title{
Hematological adjustments of the bony tongue Arapaima gigas under influence of amazonian waters
}

\author{
Cleverson Agner Ramos ${ }^{1 *}$, José Carlos Nunes Raulino ${ }^{1}$, Glauber Cruz de Menezes ${ }^{2}$, Iracimar Batista do Carmo ${ }^{2}$, \\ Elenice Martins Brasil ${ }^{2}$, Elizabeth Gusmão Affonso ${ }^{2}$, Fernandes Marisa Narciso ${ }^{3}$, Daiane Martins ${ }^{4^{*}}$
}

From 5th Congress of the Brazilian Biotechnology Society (SBBIOTEC)

Florianópolis, Brazil. 10-14 November 2013

Arapaima gigas, populary known as pirarucu is largest freshwater fish in Amazon river, with great, economic and ecological, interest. Despite being an air breather its gill structure is quite close to water breathers, especially in early stages of development [1]. However, in animals above $100 \mathrm{~g}$ the pillar cell system are embedded into the filament being the gill, an ion regulation active site. The effects of Amazonian rivers waters is well notices in fish [2], mainly by black water (BW), and white water (WW) where the ion fluxes can be meansured [3]. However information on the ionic regulation patters on this species are scarce as well implication by hematological adjustments. Such data could provide inferences on management conditions as well corroborate with what has been suggested by literature, which suggest this species as a panmitic population [4] able to deal with the hydrographic barrier formed by BW in the Amazon basin [5]. The present study aims was to analyzed $A$. gigas hematological parameters when exposed to BW and WW providing suitable hematological data concerning physiological responses in different types of water. Fish were acclimated seven days in three separated ponds containing $\mathrm{BW}, \mathrm{WW}$ and well water $(\mathrm{C})$, respectively. Control (C) fish were placed in the latter pond. Blood samples were taken from the caudal vessel at the end of acclimation period in order to perform measurement assays on levels of hemoglobin, hematocrit, mean corpuscular volume (MCV), mean corpuscular hemoglobin, mean corpuscular hemoglobin concentration, as well glucose, cholesterol and protein levels. Our findings corroborate the hypothesis stating that BW does

\footnotetext{
'Departament of Morphology, Federal University of Amazon, Manaus, Brazil ${ }^{4}$ Post Graduation Program in Biotechnology, Federal University of Amazon (UFAM), Manaus, Brazil

Full list of author information is available at the end of the article
}

interfere on fish adaptation specialy in small fish ( 100g). These lack of adaptation should be due the gill morphology of small fish which is close to other water breather fish. However in large fish $(\sim 1000 \mathrm{~g})$ the findings cleary showed that neither WW or BW can interfere on plasma profile of analysed fish. The compromisse between gas exchange and ion regulation has been demonstrated previously. As hematological adjustment plays a role on such osmorespiratory compromise, the hematological parameters data presented by this study clearly demonstrate that changes in the hematological features play a crucial role in the water to air breathing transition behavior as well in the A. gigas gill ontogenetic changes. Despite black water systems being considered a barrier constraining the dispersion of several species; this seems not to be a problem for this species which has kept its ion-regulatory mechanisms even when immerse in black waters.

\section{Authors' details \\ ${ }^{1}$ Departament of Morphology, Federal University of Amazon, Manaus, Brazil. ${ }^{2}$ Department of Aquaculture, National Institute of Amazonian Research (INPA), Manaus, Brazil. ${ }^{3}$ Departament of Physiological Sciences, Federal University of São Carlos, São Carlos, Brazil. ${ }^{4}$ Post Graduation Program in Biotechnology, Federal University of Amazon (UFAM), Manaus, Brazil.}

Published: 1 October 2014

\section{References}

1. Ramos CA, Fernandes MN, Costa OTF, Duncan WLP: Implications for Osmorespiratory Compromise by Anatomical Remodeling in the Gills of Arapaima gigas. Anat Rec 2013, 296(10):1664-1675.

2. Almeida-Val VMF, Val AL, Walker I: Long-and short-term adaptation of Amazon fishes to varying O2-levels: intra-specific phenotypic plasticity and interspecific variation. In Biology of Tropical Fishes. In Manaus: National Institute of Amazonian Research Val AL and Almeida-Val VMD , 1st 1999, 1:185-206.

3. Baldisserotto B, Copatti CE, Gomes LC, Chagas EC, Brinn RP, Roubach R: Net ion fluxes in the facultative air-breather Hoplosternum littorale 
(tamoata) and the obligate air-breather Arapaima gigas (pirarucu) exposed to different Amazonian waters. Fish Physiol Bioch 2008, 34(4):405-412, 2008.

4. Farias IP, Crossa M, Sampaio I, Porto JIR, Meyer A: Population genetic analysis of Arapaima gigas, one of the largest freshwater fishes of the Amazon basin: implications for its conservation. Animal Cons 2005, 8(3):297-308.

5. Lovejoy N, Araujo M: Molecular systematics, biogeography and population structure of Neotropical freshwater needlefishes of the genus Potamorrhaphis. Mol Ecol 2000, 9(3):259-268.

doi:10.1186/1753-6561-8-S4-P147

Cite this article as: Ramos et al: Hematological adjustments of the bony tongue Arapaima gigas under influence of amazonian waters. $B M C$

Proceedings 2014 8(Suppl 4):P147.

Submit your next manuscript to BioMed Central and take full advantage of:

- Convenient online submission

- Thorough peer review

- No space constraints or color figure charges

- Immediate publication on acceptance

- Inclusion in PubMed, CAS, Scopus and Google Scholar

- Research which is freely available for redistribution

Submit your manuscript at www.biomedcentral.com/submit
Ciomed Central 